\title{
PRELIMINARY PHYTOCHEMICAL, PHYSICOCHEMICAL, ANTIOXIDANT AND ANTIMICROBIAL STUDIES OF CLEMATIS MONTANA LEAVES
}

\author{
HEMLATA BHATT ${ }^{*}$, SARLA SAKLANI ${ }^{a}$, KUMUD UPADHAYAYb \\ aDepartment of Pharmaceutical Sciences, H. N. B. Garhwal University, Srinagar 246174, Garhwal, Uttarakhand, bDepartment of \\ Pharmaceutical Sciences, Bhimtal, Kumaun University, Uttarakhand \\ Email: visithemlata@yahoo.co.in
}

Received: 19 Jul 2016, Revised and Accepted: 20 Aug 2016

\begin{abstract}
Objective: To evaluate the phytochemical, physicochemical, antimicrobial and in-vitro antioxidant activity of Clamentis montana (Family: Rananculaceae).

Methods: The extracts were evaluated for antibacterial activity against S. aureus, B. subtilis, E. coli, P. aeruginosa by cup plate method. In-vitro antioxidant activity was done by DPPH, ferrous chelating and reducing power assay method. The physicochemical parameter like a loss on drying,
\end{abstract} total ash value, foreign matter, etc. was evaluated by standard protocol.

Results: The extract showed significant antibacterial activity against all test strains when compared with standard drugs amoxicillin. The extract showed significant antioxidant activity by DPPH method, reducing power assay and ferrous chelating method.

Conclusion: The extract showed a dose-dependent significant antibacterial and antioxidant activity.

Keywords: Clematis montana, Antibacterial, Antioxidant, Ethanolic extract

(C) 2016 The Authors. Published by Innovare Academic Sciences Pvt Ltd. This is an open access article under the CC BY license (http://creativecommons.org/licenses/by/4.0/) DOI: http://dx.doi.org/10.22159/ijcpr.2016v8i4.15274

\section{INTRODUCTION}

Clematis is a genus of climbing vines with showy flowers, and over 200 species are known. They are famous as flowering plants. Clematis montana belongs to the family Ranunculacece. Clematis montana found in Gharwal Himalaya region of Uttarakhand. Clematis montana had many medicinal properties and used for the treatment of a migraine, nervous disorders, skin infections, liver complications, hypertension and diabetes $[1,2]$. Clemontanoside $\mathrm{F}$ (triterpene bis glycoside) and three saponin \{Clemontanoside-C, [(3-0- $\beta$ ribopyranosyl) (1-3)- - -rhamnopyranosyl (l-2)-a-arabinopyranosido-28-0- $\alpha_{-L}-$-rhamnopyranosyl (l-4)- $\beta$-D-gluco-pyranosyl (1-6)- $\beta$-D-glucopyranoside of hederagenin)] [(3-0- $\beta$-ribopyranosyl (l-3)- $\alpha$-rhamnopyranosyl-(1-2)-a-arabinopyranoside of hederagenin)]\} had been isolated from Clematis Montana [3-5]. As not much work has been done on antibacterial activity, it was considered worthwhile to carry out this activity together with antifungal activity.

Free radicals are types of reactive Oxygen Species, which include all highly reactive, oxygemontaining molecules. Types of reactive Oxygen Species include the hydroxyl radical, the superoxide anion radical, hydrogen peroxide, singlet oxygen, nitric oxide radical, hypochlorite radical, and various lipid peroxides. These free radicals may either be produced by physiological or biochemical processes or by pollution and other endogenous sources. All these free radicals react with basic cell structure like membrane lipid, DNA, RNA, enzymes, etc. and damage the cell [6]. These free radicals are responsible for the development of chronic diseases such as diabetes, cancer, hypertension, cardiac infarction, arteriosclerosis, rheumatism, cataracts and others [7]. Natural antioxidants play an important role to neutralize the free radicals. Several epidemiological, clinical and experimental data suggest that plantbased antioxidants have beneficial effects on prevention on chronic diseases $[8,9]$. Plants are a rich source of free radical scavenging molecules such as vitamins, terpenoids, phenolic acids, lignins, stilbenes, tannins, flavonoids, quinones, coumarins, alkaloids, amines, betalains and other metabolites which are rich in antioxidant activity [10].

\section{MATERIALS AND METHODS}

Collection of plant material

The whole plant of Clemantis montana was collected from Dhanaulti, Mussorie Uttarakhand, India during Oct-Nov and was authenticated at Department of Botany H. N. B Garhwal University, Srinagar Garhwal, Uttarakhand by taxonomist Dr. J. K. Tewari.

\section{Preparation of extract}

The fresh leaves were dried at room temperature $\left(25-30^{\circ} \mathrm{C}\right)$ for $20 \mathrm{~d}$ and powdered. Six hundred gram of coarse powder was extracted with methanol in a soxhlet extractor for $72 \mathrm{~h}$. The solvent from total extract was distilled off and concentrated on a water bath to syrupy consistency and then evaporated to dryness. The yield was found to be $8.98 \%$.

\section{Preliminary phytochemical screening}

The qualitative chemical tests of methanolic extract of $C$. montana were carried out by using standard procedure to determine the presence of various phytochemicals [11].

\section{Physicochemical constants}

Total ash value was determined by taken accurately weighed $2 \mathrm{~g}$ of sample extract into ignited tared silica crucible where it was spread like a fine layer on the bottom. At the increasing temperature, the sample was burnt up to red hot not exceeding $450^{\circ} \mathrm{C}$ until free from carbon. Then the crucible was cooled, and resultant ash was weighed, and the thereupon percent total ash value was determined with reference to air dried extract drug. The obtained ash during the above procedure was taken and boiled with $2 \mathrm{~N} \mathrm{HCl}(25 \mathrm{ml})$ for 5 min respectively for quantitative estimation of acid insoluble ash. Thereafter the insoluble ash was recovered on an ash less filter paper and washed using hot water. The insoluble sample was transferred into a crucible which was again burnt for $20 \mathrm{~min}$ and weighed properly. In order to omit errors the whole step was repeated thrice and the percent acid insoluble ashes were determined with reference to air-dried drug. Water soluble ash was determined by using the recovered ash during the estimation for 
total ash was taken and boiled with water $(25 \mathrm{ml})$ for $5 \mathrm{~min}$ interval. Thereafter the insoluble ash was recovered on an ash less filter paper and washed using hot water. The insoluble sample was transferred into a crucible which was again burnt for $20 \mathrm{~min}$ and weighed properly. The whole step was repeated thrice in order to omit errors and the percent water soluble ashes were determined with reference to air-dried drug respectively [12-14].

\section{Loss on drying}

This parameter determines the amount of moisture as well as volatile components present in a particular sample (i.e. water drying off from the drug). The powdered drug sample (10 gm) without preliminary drying was placed on a tarred evaporating dish and dried at $105^{\circ} \mathrm{C}$ for $6 \mathrm{~h}$ and weighed. The drying was continued until two successive reading matches each other or the difference between two successive weighing was not more than $0.25 \%$. Constant weight was reached when two consecutive weighing after drying for $30 \mathrm{~min}$ in a desiccator, showed not more than $0.01 \mathrm{gm}$ difference [15].

\section{Foreign matter}

It is the matter present in the drug. Its presence may be due to a faulty collection of crude drug or due to deliberate mixing. It was separated from the drug so that results obtained from analysis of the drug gives accuracy. Its percentage in the crude drug was calculated.

\section{In vitro antioxidant studies}

\section{(a) DPPH method}

\section{Preparation of extract standard dilution}

$25 \mathrm{mg}$ of ethanolic extract of leaves was weighed and dissolved in 25 $\mathrm{ml}$ of methanol to get $1000 \mu \mathrm{g} / \mathrm{ml}$ stock solution. Lower concentrations $(100,200,300,400 \mu \mathrm{g} / \mathrm{ml})$ was prepared by diluting serially with methanol. Ascorbic acid was weighed $(10 \mathrm{mg})$ and dissolved in $100 \mathrm{ml}$ methanol to get $100 \mu \mathrm{g} / \mathrm{ml}$ stock solutions. Lower concentrations $(2,4,6,8,10 \mu \mathrm{g} / \mathrm{ml})$ was prepared by diluting serially with methanol.

\section{Method}

The stable 1, 1-diphenyl-2-picryl hydroxyl radical (DPPH) was used for determination of free radical-scavenging activity of the extract. $50 \mathrm{mmol}(0.00147 \mathrm{gm}$ in $50 \mathrm{ml})$ solution of DPPH in methanol was freshly prepared. Different concentrations of extract and standard were added to the equal volume of a methanolic solution of DPPH. After $30 \mathrm{~min}$ at room temperature, the absorbance was recorded at $517 \mathrm{~nm}$. A control reaction was carried out without the test sample. $\mathrm{IC}_{50}$ values denote the concentration of the sample, which is required to scavenge $50 \%$ of DPPH free radicals. Radical scavenging activity was calculated by the following formula

$$
\% \text { Inhibition }=\left(\mathrm{A}_{0}-\mathrm{A}_{1}\right) / \mathrm{A}_{0} \times 100
$$

where $\mathrm{A}_{0}$ is the absorbance of control and $\mathrm{A}_{1}$ is the absorbance of extract or standard.

$\mathrm{IC}_{50}$ value was determined from the plotted graph of scavenging activity against the different concentrations of C. montana extracts, which is defined as the concentration of antioxidant necessary to decrease the DPPH radical concentration by $50 \%$. The measurements were carried out three times, and their scavenging effect was calculated based on the percentage of DPPH scavenged [16].

\section{(b) Ferrous chelating activity}

$1 \mathrm{ml}$ of each dilution of ethanolic extract $(200-1000 \mu \mathrm{g} / \mathrm{ml})$ and standard BHT $(100-400 \mu \mathrm{g} / \mathrm{ml})$ was added to a solution of $2 \mathrm{mmol}$ ferrous chlorides $(0.2 \mathrm{ml})$. The reaction was initiated by the addition of $5 \mathrm{mmol}$ ferrozine $(0.4 \mathrm{ml})$. The total volume was adjusted to $4 \mathrm{ml}$ with ethanol. Then, the mixture was shaken vigorously and kept at room temperature for $10 \mathrm{~min}$. The absorbance of the solution was measured spectrophotometrically at $562 \mathrm{~nm}$ [17].

\section{(c) Reducing power}

$1 \mathrm{ml}$ of ethanolic extract $(100-400 \mu \mathrm{g} / \mathrm{ml})$, standard ascorbic acid dilutions $(20-100 \mu \mathrm{g} / \mathrm{ml})$ and control sample $(1 \mathrm{ml}$ distilled water instead of sample solution) was mixed with $2.5 \mathrm{ml}$ phosphate buffer solution (pH 6.6) and $2.5 \mathrm{ml}$ potassium ferricyanide (1\%). The final mixture was properly mixed and incubated at $50{ }^{\circ} \mathrm{C}$ for $20 \mathrm{~min}$. After incubation, the reaction mixture was rapidly cooled and mixed with $2.5 \mathrm{ml}$ of $10 \%$ trichloroacetic acid. It was centrifuged at $3000 \mathrm{rpm}$ for $10 \mathrm{~min}$. About $2.5 \mathrm{ml}$ of the supernatant was taken, and $2.5 \mathrm{ml}$ distilled water and $0.5 \mathrm{ml}$ of ferric chloride $(0.1 \%)$ were added, it was mixed well and allowed to stand for $10 \mathrm{~min}$. The absorbance was measured at $700 \mathrm{~nm}$ [18].

\section{Antimicrobial activity}

The ethanolic extract of leaves was examined for antibacterial activity against Gram-positive bacteria $S$. aureus, B. subtilis, Gramnegative bacteria $E$. coli, $P$. aeruginosa and antifungal activity against C. albicans. The antimicrobial screening was performed by agar well diffusion method. Muller Hinton Agar medium (Hi-media) and Sabouraud agar medium were used for bacterial and fungal strains respectively. The mediums were sterilized by autoclaving at $120^{\circ} \mathrm{C}$ for $25 \mathrm{~min}$ and poured into Petri-plates and allowed to solidify. The plates were swabbed with the bacterial strains of $S$. aureus, $B$. subtilis, E. coli, $P$. aeruginosa and fungal strain of $C$. albicans. In each plate wells of $6 \mathrm{~mm}$ diameter were made at equal distances using sterile cork borer. Different dilutions of the extract were made having concentration of $100 \mu \mathrm{g} / \mathrm{ml}, 250 \mu \mathrm{g} / \mathrm{ml}, 500 \mu \mathrm{g} / \mathrm{ml}$, and $1000 \mu \mathrm{g} / \mathrm{ml}$ in DMSO (dimethyl sulphoxide). $0.1 \mathrm{ml}$ of each test solution and control were placed in $6 \mathrm{~mm}$ diameter wells. One well was filled with $0.1 \mathrm{ml}$ of standard drug Amoxycillin $(10 \mu \mathrm{g} / \mathrm{ml})$ in the case of antibacterial activity whereas standard drug Fluconazole $(10$ $\mu \mathrm{g} / \mathrm{ml}$ ) in antifungal activity. The Petri plates were incubated at 37 ${ }^{\circ} \mathrm{C}$ for $24 \mathrm{~h}$ for antibacterial and at about $28^{\circ} \mathrm{C}$ for $48 \mathrm{~h}$ for antifungal activity respectively. The diameter of the zone of inhibition was measured [19]. The diameter obtained for the test samples were compared with diameter produced by the standard Amoxycillin and fluconazole in antibacterial and antifungal activity.

\section{RESULTS AND DISCUSSION}

\section{Preliminary phytochemical screening}

Ethanolic extract of Clemantis montana leaves showed the presence of carbohydrates, tannins, steroids, triterpenoids, saponins and flavonoids table 1 . Medicinal plants are a great source of active constituents for the development of new therapeutic compounds.

Table 1: Results of preliminary phytochemical investigation of ethanolic extracts of $C$. montana leaves

\begin{tabular}{lll}
\hline S. No. & Test & Leaves \\
\hline 1. & Alkaloids & - \\
2. & Carbohydrates & + \\
3. & Steroids and Sterols & + \\
4. & Flavonoids & ++++ \\
5. & Tannins & +++ \\
6. & Triterpenoids & + \\
7. & Saponin Test & + \\
\hline
\end{tabular}

\section{Physicochemical parameters screening}

Physicochemical parameters of Clemantis montana leaves has been depicted in table 2 . The percentage of total ash, acid insoluble ash, water soluble ash value has been found $8.20,1.50$ and $2.28 \%$ respectively. The extractive value has been found $16.64 \%$ in water and $7.52 \%$ in alcohol. $2 \%$ foreign matter and $8.9 \%$ moisture content has been found in Clemantis Montana leaves. These herbal drugs were standardized as per WHO guidelines. The moisture content or loss on drying less than the limit, it means less chances of bacteria, fungi or yeast growth. Ash value of a drug gives an idea of the earthy matter or inorganic composition, and other impurities present along with the drug. Extractive values are primarily useful for the determination of exhausted or adulterated drugs. All these parameters, which are being reported, could be useful in identification of distinctiveness features of the drug and also valuable in manufacturing as raw material or in prescription medicine. 
Table 2: Physicochemical parameters of Clemantis montana

\begin{tabular}{llll}
\hline S. No. & Physicochemical parameter & Type & Observed value (\% w/w) \\
\hline 1. & Ash value & Total ash & 8.20 \\
& & Acid insoluble ash & 1.50 \\
& & Water soluble ash & 2.28 \\
2. & Extractive value & Alcohol soluble value & 7.52 \\
& & Water soluble & 16.64 \\
3. & Foreign matter & & 2 \\
\hline
\end{tabular}

\section{In vitro antioxidant studies}

\section{DPPH method}

The DPPH free radicals scavenging activity has been shown in table 3. The IC $\mathrm{I}_{50}$ value was found to be $151.50 \mu \mathrm{g} / \mathrm{ml}$ for extract and 6.727 $\mu \mathrm{g} / \mathrm{ml}$ for ascorbic acid. DPPH (1, 1-diphenyl-2-picryl hydrazyl radical) is commonly used to find out the anti-oxidant property of plants extract. When DPPH react with the antioxidant, it's converted into DPPHH and absorbance decreases from DPPH radical to DPPH$\mathrm{H}$ form [20]. In the presence of antioxidant molecules, DPPH dark purple colour change to a colourless solution. Discoloration of DPPH solution directly proportional to antioxidant property of the sample.

Table 3: IC 50 value of ethanolic extract of leaves of Clementis montana and standard ascorbic acid by DPPH method

\begin{tabular}{|c|c|c|c|c|}
\hline S. No. & Extract & & Ascorbic acid & \\
\hline & Concentration $(\mu \mathrm{g} / \mathrm{ml})$ & \%inhibition & Concentration $(\mu \mathrm{g} / \mathrm{ml})$ & \%inhibition \\
\hline 1 & 100 & 40.97 & 2 & 13.22 \\
\hline 2 & 200 & 58.42 & 4 & 23.42 \\
\hline 3 & 300 & 72.56 & 6 & 43.24 \\
\hline 4 & 400 & 80.66 & 8 & 59.04 \\
\hline \multirow[t]{2}{*}{5} & & & 10 & 80.22 \\
\hline & IC 50 & $151.50 \mu \mathrm{g} / \mathrm{ml}$ & IC 50 & $6.727 \mu \mathrm{g} / \mathrm{ml}$ \\
\hline
\end{tabular}

\section{Ferrous chelating activity}

In the case of the ferrous chelating method, chelating rate has been increased with the increasing concentration of ethanolic extract of
Clemantis Montana leaves, but it is less compare to the standard BHT (table 4). In metal chelating assay, ferrozine forms a magenta colour complex with $\mathrm{Fe}^{2+}$. In the presence of an antioxidant, the colour intensity of the sample decreases [21].

Table 4: $\mathrm{IC}_{50}$ value of ethanolic extract of leaves of Clementis montana and standard BHT by ferrous chelating method

\begin{tabular}{|c|c|c|c|c|}
\hline S. No. & Extract & & BHT & \\
\hline & Concentration $(\mu \mathrm{g} / \mathrm{ml})$ & \%inhibition & Concentration $(\mu \mathrm{g} / \mathrm{ml})$ & \%inhibition \\
\hline 1 & 200 & 32.25 & 100 & 44.12 \\
\hline 2 & 400 & 43.52 & 200 & 52.24 \\
\hline 3 & 600 & 54.63 & 300 & 64.26 \\
\hline 4 & 800 & 66.81 & 400 & 82.21 \\
\hline \multirow[t]{2}{*}{5} & 1000 & 72.44 & & \\
\hline & $\mathrm{IC}_{50}$ & $532.94 \mu \mathrm{g} / \mathrm{ml}$ & $\mathrm{IC}_{50}$ & $165.63 \mu \mathrm{g} / \mathrm{ml}$ \\
\hline
\end{tabular}

\section{Reducing power assay}

$\mathrm{IC}_{50}$ value in reducing power assay $254.5 \mu \mathrm{g} / \mathrm{ml}$ for extract and 43.7 $\mu \mathrm{g} / \mathrm{ml}$ for standard (table 5). Substances, which have reduction potential, react with potassium ferricyanide (Fe3+) to form potassium ferrocyanide $\left(\mathrm{Fe}^{2+}\right)$, which then reacts with ferric chloride to form a ferric ferrous complex that has an absorption maximum at $700 \mathrm{~nm}$. These assays are known as a robust and useful method for measuring a wide concentration range of antioxidant activities and capacities [22].

Table 5: IC 50 value of ethanolic extract of leaves of Clementis montana and standard ascorbic acid by reducing power assay

\begin{tabular}{lllll}
\hline S. No. & Extract & & ascorbic acid & \\
\cline { 2 - 5 } & Concentration$(\boldsymbol{\mu g} / \mathbf{m l})$ & Absorbance & Concentration( $\boldsymbol{\mu g} / \mathbf{m l})$ & Absorbance \\
\hline 1 & 100 & 0.212 & 20 & 0.282 \\
2 & 200 & 0.452 & 40 & 0.48 \\
3 & 300 & 0.624 & 60 & 0.672 \\
4 & 400 & 0.894 & 80 & 0.884 \\
5 & & $254.5 \mu \mathrm{g} / \mathrm{ml}$ & 100 & 1.12 \\
& IC 50 & & IC $_{50}$ & $43.7 \mu \mathrm{g} / \mathrm{ml}$ \\
\hline
\end{tabular}

\section{Antimicrobial activity}

Antimicrobial activity was carried out for ethanolic extract of leaves of Clemantis montana. The data for antibacterial and antifungal activity is listed in Table-6. From the data, it is evident that ethanolic extract of leaves of Clemantis montana showed the greater zone of inhibition against gram-positive than gram-negative bacteria.
This shows that gram-positive bacteria are more susceptible than gramnegative bacteria. The extract also showed significant antifungal activity against $C$. albicans. The results of present study indicate that the plant extract showed both antibacterial and antifungal activity against the test organisms which might be due to the phytoconstituents present in the leaves. 
Table 6: Antimicrobial activity of ethanolic extract of Clemantis montana leaves

\begin{tabular}{|c|c|c|c|c|c|}
\hline \multirow[t]{4}{*}{ Concentration } & \multicolumn{5}{|c|}{ Zone of inhibition (mm) of Clemantis Montana leaves } \\
\hline & \multicolumn{4}{|c|}{ Antibacterial activity } & \multirow{3}{*}{$\begin{array}{l}\text { Antifungal } \\
\text { C. albicans } \\
\end{array}$} \\
\hline & \multicolumn{2}{|c|}{ Gram-positive } & \multicolumn{2}{|c|}{ Gram-negative } & \\
\hline & S. aureus & B. subtilis & E. coli & P. aeruginosa & \\
\hline $100 \mu \mathrm{g} / \mathrm{ml}$ (extract) & 10 & 11 & 18 & 15 & 14 \\
\hline $250 \mu \mathrm{g} / \mathrm{ml}$ (extract) & 14 & 18 & 21 & 22 & 16 \\
\hline $500 \mu \mathrm{g} / \mathrm{ml}$ (extract) & 18 & 20 & 24 & 23 & 19 \\
\hline $1000 \mu \mathrm{g} / \mathrm{ml}$ (extract) & 21 & 24 & 28 & 25 & 22 \\
\hline Control & -- & -- & -- & -- & -- \\
\hline Amoxycillin $10 \mu \mathrm{g} / \mathrm{ml}$ & 13 & 14 & 11 & 12 & -- \\
\hline Fluconazole $10 \mu \mathrm{g} / \mathrm{ml}$ & -- & -- & -- & -- & 22 \\
\hline
\end{tabular}

\section{CONCLUSION}

As per above-mentioned results of antioxidant, it is concluded that $C$. Montana can be a potential source of antioxidant. This extract shows significant antibacterial and antifungal activity in comparison with amoxicillin and fluconazole respectively.

\section{ACKNOWLEDGEMENT}

We, the authors are thankful to H. N. B. Garhwal, University Srinagar, Garhwal, Uttarakhand for providing facilities and encouragement.

\section{CONFLICTS OF INTERESTS}

We declare that we have no conflict of interest

\section{REFERENCES}

1. Sastri BN. The Wealth of India. (Publication and Information Directorate, CSIR. Hillside. New Delhi, India; 1962. p. 336.

2. Dhar ML, Dhar MC, Dhawan BN, Mehtrotra BN, Ray C. Screening of Indian plants for biological activity. Indian J Exp Biol 1968;2:232-47.

3. Thapliyal RP, Bahuguna RP. An oleanolic acid based bis glycoside from Clematis montana roots. Phytochemistry 1993;34:861-2.

4. Bahuguna RP, Thapliyal RP, Murakami N, Tanase T, Kaiya T, Sakakibara. Saponins from Clematis Montana. Pharm Biol 1990;28:125-7.

5. Thapliyal RP, Bahuguna RP. Clemontanoside-C. A saponin from Clematis montana. Phytochemistry 1993;33:671-3.

6. Shivaprasad HN, Mohan S, Kharya MD, Shiradkar RM, Lakshman K. In vitro models for antioxidant activity evaluation: a review. Latest Rev 2005;3:981-96.

7. C Soler-Rivas, JC Espin, HJ Wichers. An easy and fast test to compare total free radical scavenger capacity of foodstuffs. Phytochem Anal 2000;11:330-8.

8. B Halliwell. Free radicals, antioxidants, and human disease: curiosity, cause, or consequence? Lancet 1994;344:721-4.

9. JC Espin, C Soler-Rivas, HJ Wichers. Characterization of the total free radical scavenger capacity of vegetable oils and oil fractions using 2,2-diphenyl-1-picrylhydrazyl radical. J Agric Food Chem 2000;48:648-56.

10. RL Prior. Fruits and vegetables in the prevention of cellular oxidative damage. Am J Clinic Nutr 2003;78(3 Suppl)570S-578S.
11. Aiyegoro OA, Okoh AI. Preliminary phytochemical screening and In vitro antioxidant activities of the aqueous extract of Helichrysum longifolium DC. BMC Complementary Altern Med 2010;10:1-8.

12. Kokate CK. Practical pharmacognosy. Vallabh prakashan, New Delhi, India; 2005. p. 107-11.

13. Indian Herbal Pharmacopoeia. Vol. I. Tanushree Enterprises, Worli Naka, Mumbai; 2007. p. 179-81.

14. Indian Pharmacopoeia. Vol. II. The Controller of Publications, New Delhi; 1996. p. A52-A54.

15. WHO/PHARM/92.559/rev. 1. Quality Control Methods for Medicinal Plant Materials, Organisation Mondiale De La Sante, Geneva: 1992. p. 22-34.

16. Curcic MG, Stankovic MS, Radojevic ID, Stefanovic OD, Comic LR, Topuzovic MD, et al. Biological effects, total phenolic content and Flavanoid concentrations of fragrant yellow onion (Allium flavum L.). Med Chem 2012;89:1-6.

17. Robu S, Aprotosoaic AC, Miron A, Cioanca O, Stanescu U, Hancianu M. In vitro antioxidant activity of ethanolic extracts from some Lavandula species cultivated in Domania. Farmacia 2012;60:394-401.

18. Maisarah AM, Nurul Amira B, Asmah R, Fauziah O. Antioxidant analysis of different parts of Carica papaya. Int Food Res J 2013;20:1043-8.

19. Reeves, Wise, Andrews and White. Clinical Antimicrobial Assay. Oxford University, New York; 1999. p. 24-5.

20. Moein MR, Moein S, Ahmadizadeh S. Radical scavenging and reducing the power of Salvia mirzayanii subfractions. Molecules 2008;13:2804-13.

21. Fukomoto LR, Mazza G. Assessing antioxidant and prooxidant activities of phenolic compounds. J Agric Food Chem 2000;48:3597-604.

22. Bors W, Michel C. Antioxidant capacity of flavanols and gallate esters: pulse radiolysis studies. Free Radical Biol Med 1999;27:1413-26.

\section{How to cite this article}

- Hemlata Bhatt, Sarla Saklani, Kumud Upadhayay. Preliminary phytochemical, physicochemical, antioxidant and antimicrobial studies of Clematis montana leaves. Int J Curr Pharm Res 2016;8(4):33-36. 